\title{
Les Cahiers de droit
}

\section{Errata}

E. C.

Volume 10, numéro 3, 1969

URI : https://id.erudit.org/iderudit/1006454ar

DOI : https://doi.org/10.7202/1006454ar

Aller au sommaire du numéro

Éditeur(s)

Faculté de droit de l'Université Laval

\section{ISSN}

0007-974X (imprimé)

1918-8218 (numérique)

Découvrir la revue

Citer ce document

C., E. (1969). Errata. Les Cahiers de droit, 10(3), 414-414.

https://doi.org/10.7202/1006454ar

Ce document est protégé par la loi sur le droit d'auteur. L'utilisation des services d'Érudit (y compris la reproduction) est assujettie à sa politique d'utilisation que vous pouvez consulter en ligne.

https://apropos.erudit.org/fr/usagers/politique-dutilisation/ 


\section{ERR A T A}

Nous avons constaté quelques erreurs qui se sont glissées dans le numéro 1 du présent volume.

- Le titre de l'article du professeur SkELLY est bien : «Divorce Reform, A Reality». L'erreur se trouve dans le dernier mot de ce titre en page couverture, dans le sommaire à la page 1, dans la table des matières et dans le sommaire à l'endos du volume.

- A la page 167, la N.D.LE. doit se lire : Nous remercions monsieur le professeur Henri BRUN et monsieur Jean Gouler qui ont bien voulu relire et corriger ce texte quant $\dot{a}$ la forme». Ces derniers mots avaient été omis lors de l'impression.

Nous nous excusons auprès du professeur SkEl.ty et monsieur Heleine.

E. C. 